\title{
Accentuating on Self-Concept to obviate Suicidality through the novel 13 Reasons why by
} Jay Asher

\author{
Roshanara. M.S, Ramya.S
}

\begin{abstract}
Suicide is an act of taking away life by assassinating one's own self. The act of committing suicide remains as the way to escape from facing the reality of life. It is considered to be an unnatural death, where the reason behind suicide is either unspecified or stated in suicide. The major reason behind the act of committing suicide is the mental illness and severe depression. This depression has been caused due to several reasons, which can be categorized in various aspects and the major aspects are familial aspect, financial aspect, social aspect, abusive aspect and individual aspect. In such case, the individual experiences great emotional pain, where the individual thinks that the only way to get out of the pain is by ending one's life. This paper would serve its best to eradicate the suicidal thoughts from human minds despite the reasons.
\end{abstract}

Keywords-depression, mental illness, pain, suicide, unnatural death.

\section{INTRODUCTION}

\subsection{Statement of the problem}

Ending life through suicide cannot be the way to tackle problems and in the novel 13 Reasons why, the protagonist Hannah Baker commits suicide, as she has experienced painful incidence in her life. She commits suicide, to escape the reality of her life and she blames others for her death. The researcher analyzes that the real cause for Hannah's suicide does not rely upon the reasons she has stated on people, but it's about her hopelessness that she felt at a point in her life. Whereas, she ends her life thinking that nothing would be made straight in her life and the only option that she has is to take away her own life. The depressiveness and hopelessness sprung into her character, when she meets with low-self-esteem in her character.

The problem is stated clearly with the help of The Interpersonal Theory of Suicide, which has been developed by Thomas Joiner, the American Academic Psychologist and a leading expert on suicide. This theory provides three major components, which leads to suicide attempt.

The below mentioned are the three components that leads to suicide attempts:

- Thwarted belongingness

- Perceived burdensomeness

- Acquired capability

\subsection{Review of literature}

Sherman Alexie, who had been the bestselling author of The Absolutely True Diary of a Part- Time Indian, states that the novel 13 Reason Why had been filled with enigma, speech of praise and protocol and she says that she had shut the novel twenty to thirty times, whenever she had come across beautiful or painful dialogues. Though she was petrified, she returned to this book because of the curious state that this book holds on to.

Ellen Hopkins, who had been the bestselling author of Ticks, Identical, Burned etc., says that people would come across many books in their life and only a few books would get hold of their mind and 13 Reasons Why is one among them, where people would find difficult to put that book down for a reason.

Gordon Korman, who had been the author of Son of the Mob and Jake, Reinvented, says that 13 Reasons why is a picturesque first novel written by Jay Asher, which tells the story of uprightness and plainness, where the devastation feels dashingly real.

\subsection{Objectives of the study}

- To prove that low self-esteem would prevail ways to take individuals life. The protagonist in the novel suffers with low self-esteem, which has been seen through the lack of confidence and through the pessimistic tone of the character.

- To prove that being voiced would help individuals to sustain their self-esteem. The particular character in the novel proves it through her action. The character Courtney maintains her self-image and proves herself to be a self-esteemed person. 
- To prove that being voiceless would make individuals to leave their unwanted footprints in other individual's life. The character Hannah baker suffers because of the rumors created by her friends and she failed to maintain her self-esteem.

\subsection{Scope of research}

Despite death being a natural one, people tend to take away their own life, when they feel that they cannot cope with their life anymore. According to The World Health Organization, approximately one million people lose their life by suicide. People commit suicide for every forty seconds. Approximately one million people lose their life by suicide. It is predicted that "People might commit suicide for every twenty seconds by 2020 " (Web). It is mandatory to find a solution to prevent death by suicide. This also focuses on the reasons, which force people to think of losing their own life, more than to fight with it.This research would provide a valid solution for people, who voluntarily lose their own life without knowing the importance of life. The scope of this research would be finding the ways to prevent suicidal thoughts and attempt of committing suicide, by analyzing the lack of certain qualities in the characters, who commits suicide.

\section{ANALYSIS BASED ON THE TRIO OF SELF- CONCEPT}

The novel 13 Reasons Why, revolves around suicide and suicidal thoughts of a character named Hannah Baker and there are several other characters, which comes along her way. Hannah states them as the reason for her death. This analysis does not focus on the reasons behind Hannah's death and at the same time, it is not justifying her suicide attempt. It is to oppose her behavioral attitudes towards people, who have ill-treated her. This character remains passive to maltreatments caused by her friends. She just blames them for their actions towards her, which portrays her character as weak and sick. Throughout the novel, Hannah carries her character in a weak manner, where she walks on the ugly platform created through rumors by her own classmates and friends. Finally, she commits suicide after stating the reasons for her death, by recording it through cassette tapes. This character has lost the game of life, as she failed to play it carefully, just like walking on the edge of razor. The chapter focuses on analyzing the character, rather than analyzing the situation and reason behind the suicidal thoughts. This helps to know the defect and the lack of certain quality in a character, which makes them to react in a wrong way of losing one's life, more than to fight with it.
"I hope you're ready, because I'm about to tell you the story of my life. More specifically, why my life ended. And if you're listening to these tapes, you're one of the reasons why" (7). This is how Hannah begins her thirteen reasons behind her suicide and she had planned in a perfect manner, where she distributes the tapes to all the people, whom she considers as the reason for her death. The way she packed the recordings seem to be systematic, but the poor thing is that, this girl did not carry her life systematically and if she has carried out her life in an orderly way, she would not have lost her life. Hannah's execution of these tapes did not favor her at any of the ways, but she had made people to be in her shoes by making them to listen, how she felt when people ill-treated her. She makes a map for each person in the tape and instructs them to follow the map, while they are listening to her recordings and this shows the smart character of Hannah. This character had failed to put on her smartness to lead her life effectively and she gave up her life for the sake of others.

This text has been analyzed based on the selfconcept, which seems to be the belief that one has about themselves and this is a self-constructed way, which would help people to elevate one's life. According to Carl Rogers, there are three components which are essential for a human to live life peacefully with strength, courage and patience. The components are stated below

\section{- Self-image \\ - Self esteem \\ - Ideal self}

This analysis is to state and prove that a person without the self-image, self-esteem and ideal-self, would prevail way to take away their own life. This is interpreted through the character of the protagonist in the novel 13 Reasons Why. This helps to know the importance of self and self-concept in individual's life, which would help them to avoid suicide and suicidal thoughts. This analysis would help people to boost themself with self-confidence and courage to break the worst idea of losing their life.

\subsection{Self-image}

Self-image is the way the individual sees themselves and how they perceive their personality traits. It's more about knowing themselves and what they really mean to this society. Knowing the purpose of life and being connected with social roles, will help a person to develop their selfimage, which would provide a way to project themselves in this society both physically and mentally. Self-image does not rest within the physical description but it is more about 
the self-description and it is the love that one possesses for themselves, which creates a sense of self belongingness and this helps in evoking confidence in people. "There are some sick and twisted people out there, Alex-and maybe I'm one of them- but the point is when you hold people up for ridicule, you have to take responsibility. When other people act on it" (53).

Hannah through these words reveals herself that she is sick and twisted. This portrays her character as weak and sensitive, where she keeps on blaming people for her death. This nature of Hannah shows that she lacks self-image. It is to be considered that Hannah has been ridiculed by people around her. People will never take responsibility for their action and reaction on another people and this is the bitter truth of life. It is foolish for people to think of holding responsibility for other's life. Hannah could have realized the fact, that no one would feel responsible for her life more than herself. She could have known this, if she has been built with self-image.

"And yet the whole time Courtney was using me, she probably thought she was polishing up her image in my eyes" (110). These lines where spoken by Hannah, when Courtney her former friend called her for a party. Here, Hannah loses her self-image and reputation by joining the party with Courtney. This is because, Courtney has left Hannah alone after knowing that Hannah's reputation has been spoiled, due to rumors about her character. Courtney does not want her reputation to get spoiled because of her friendship with Hannah. Thus, just to hide her lesbianism from people, she accuses Hannah as a slut and avoids her. Hannah even after knowing all these, she accompanied Courtney and she blames for abandoning her in the party. She feels that she has been used by Courtney as a driver. Individual with self-image will be aware of their social roles with people. After being deteriorated beyond the social roles, a self-imaged person would retain their life with restraint, which would structure and sage guard their life. Hannah is portrayed as a person without self-image, where she fails to see herself respectfully and this paved way for people to outrage her. Hannah worried for losing people in her life, but she did not realize that they did not deserve her friendship. If Hannah has been a self-constructed person, she would not have left people to spread rumors about her. She would have raised her voice against the people, who tormented her. This shows the voiceless character of Hannah.

\subsection{Self-esteem}

Self-esteem is all about knowing one's own worth and feeling satisfied. It is the way of recognizing and maintaining the characteristic qualities, without damaging it by comparing with people in the society. A person with selfesteem will always appreciate themselves for their goodness more than expecting it from other. They do not always need a person to boost them up and rather they self-motivate themselves. A self-esteemed person would accept themselves as they are and later, they try to develop their personality traits. They do not pay attention to what people think about them rather, they always exhibit positivity in their thoughts. Person with self-esteem will never be used by other people. Critical thinking is quite seen in people with self-esteem, where they would never fall for unknown. Before approaching any sort of situations, they always seek for opportunities and obstacles. They will never leave people to take them for granted and the protagonist of 13 Reasons Why, has been taken for granted by the people around her and she has also been the reason for that.

On the other hand, the lack of self-esteem makes people to evaluate themselves by comparing their life with the life of other people, where they expect more and gets disappointed. This disappointment makes them to give away their self-confidence. People with low self-esteem tries to live the life of someone else, where they do not actually belong to. They always pay more attention on what people think about them. These sorts of people do not actually belong to themselves and this would create a depression in them. This, in most of the circumstances results in suicide and suicidal thoughts.

In the novel 13 Reasons Why, Hannah Baker suffers with low self-esteem, she ruins her life by committing suicide. She has been depressed and hopeless throughout the novel. "I know what you're all thinking Hannah Baker is a slut. Oops. Did you catch that? I said, "Hannah Baker is." Can't say that anymore" (23). Hannah longed to be with a guy named Justin, who has been the best athlete. She secretly admires him and she wishes to have a kiss from him. Her dreams come true but before recognizing it as a wonderful memory, it has become a worst part of her life. The memories turn as a rumor by her fellow classmates, where they accuse Hannah for illicit relationship with Justin and her classmates tags her as slut. When Hannah confers this with Justin, she comes to know that Justin himself has created the rumor. After hearing this, Hannah becomes voiceless. She tries to explain herself to people, but none of them believes her. This character cannot be justified and empathized for her decision of committing suicide. If Hannah has been a selfesteemed person, she would have thought twice before committing suicide. Succumbing life is similar to 
disintegrating the self-worth, courage and confidence. It is moreover like giving up on one's self. A self-esteemed person will never give up, despite the situations. She should have thought about not to end her life for the words of worthless people. Hannah should have realized that, some beautiful minds deserve her tears of joy. She should not have wasted her tears by shedding it for counterfeit people. Hannah instead of fighting bravely against the rumors, she falls prey to the rumors and this shows the deceased character of Hannah.

"It gives people - some people - the go ahead to treat you like you're nothing but the specific body part" (44). These lines undoubtedly signify the reticent character of Hannah, where she has left people to spit their mucus in her life. When things go beyond the boundary, people are in need to react, in order to maintain their reputation. However, if people fail to react, they would fall into the foot prints of other people, where people print their foot according to their wish. "I've had my butt grabbed before-no big deal-but this time it was grabbed because someone else wrote my name on a list" (52). The words spoken by Hannah fairly exhibits that, she has been harassed several times. The voiceless nature of the protagonist denotes that, somewhere in-between her lack of self-belongingness and burdensomeness, she has lost her self-esteem. If the character has known the importance of self-worth, she would not have been voiceless. She would have raised her voice against the violence, which wipes off her dignity. Self-esteem is a pride and it is the attire, which every individual should wear to protect themselves from the disrepute. This character Hannah lives her life with humiliation and she fails to step forward to abolish the humiliation out of her life. She is numb and finds no interest to rejuvenate her life. She tries to beautify her character by wearing the ornament of self-esteem but she stains her soul by taking away her life, without knowing the worth of life.

Courtney is the friend of Hannah and she accompanies Hannah when she has been alone at her home, later she kisses Hannah. The year book photographer Taylor, secretly peeps into Hannah's bedroom and takes picture of Courtney, while she kisses Hannah. Later he sends it to whole school. Courtney has been respected and admired by everyone in her school including Hannah Baker. Courtney's friends enquire her about the about the picture. Courtney to hide her lesbianism from people and to maintain her reputation, she denies that it is not her but Hannah with her friend, Laura. Courtney after realizing that her reputation is safe from people, she starts to spread sexual rumors about
Hannah to safe guard her lesbianism, so that people would not pay attention to her. Though Courtney has been portrayed as a bad character in the novel, she does not give away her self-esteem and she tries to maintain a self-image, which makes people to feel happy and proud about her. Courtney hides her bad qualities and maintains reputation around people. But Hannah though being good natured, she fails to save her reputation and also fails to create her self-image.

"Courtney Crimson. What a pretty name. And yes, a very pretty girl, as well. Pretty hair. Pretty smile. Perfect skin. And you're also very nice. Everyone says so" (93). These lines constitute how Courtney has made up her selfimage and has been retaining self-esteem, despite her flaws. The very word of Hannah 'everyone say so' shows that Courtney has presented her character in appreciable sense, but it is not her real character. She portrays herself as another person in front of the people around her. Every individual needs to be another individual, when they step out of their personal surrounding and this would help them to maintain their self-esteem. Thus, Courtney is seen as a voiced character, where she sustains her self-esteem and she has not left people to create rumors about her. In spite of being a flawed character, Courtney has created a flawless self-image in front of people around her. Though she is a lesbian, she does not under estimate herself and she maintains her reputation.

\subsection{Ideal self}

Ideal self is the glorified version of individuals, which has been created out of individual's life experience. It also involves the demand of society and how people make their life according to their inspirations, despite the demand made by the society. There is a huge difference between the ideal self and the self-image. Ideal self is the self, which helps individual to know about whom they wanted to be. Whereas, the self-image is all about, who the individual is and what their social roles in the society. Ideal self is not actually who you are at the present, but it is all about who you would be after a month or years from now. It is the way of self-exploration, which helps individual to know about what they really need in their life or what they actually need to be in their life. When the individual begins to quest their own desires, they would become eager to make their life colorful. Throughout this process, the individual would come across many obstacles, but they would not pay attention to it. This is because the individual very well know their destination point and they would not stop at the middle of hurdles. 
The individual without ideal self would always think about the criticisms and the drawbacks around them and they fail to utilize their time effectively. Here, the individual fail to achieve the desires of their life and they fail to satisfy themselves by not becoming what they really have to become. At a point of time, the individual even fails to know about what they actually need in their life or what they have to realize about themselves. In the novel 13 Reasons why, the protagonist Hannah Baker fails to acquire ideal self. And if she has possessed ideal self, she would not have fallen as victim of rumors and she would not have demolished her life for the sake of wretched people. She would have got many other goals to achieve in her life, more than to think of unwanted experiences. She would have crossed the obstacles just like a cake walk to achieve the real purpose of her life, which would make her life meaningful. This girl gets stuck at the middle of her life, without any purpose of stopping at the middle. This shows that she has not set any destination point in her life and thus she ends her life abruptly.

Life gives several experiences and every obstacle in life would demand a new self from the existing self. Hence, modulation in life is necessary to make life meaningful and also to search for the exact purpose of life. Every individual should be like a melted candle, just to take the various shapes that the circumstance demands to take. So that the individual would feel complete despite the incompleteness in their character and they could become what they actually dreamt to become.

I wanted people to trust me, despite anything they'd heard. And more than that, I

Wanted them to know me. Not the stuff they thought they knew about me. No, the

Real me. I wanted them to get past the rumors. To see beyond the relationships I

Once had, or maybe still had but that they didn't agree with. (135)

This reveals the lack of ideal self in Hannah, where she thinks more about people and their thoughts. She has not given any personal space for her own self, where she fails to create a self-bond. She took all rumors to her heart and killed her own self.

Throughout the novel, Hannah observes and explores how people value her and how they mishandle her. She has not self-explored herself, to find what she really needs in her life and how she needs to abolish the rumors. This poor girl did not recognize that not paying attention to rumors is the way to divert the attentiveness of rumors. She wants people to trust her despite the rumors. Though Hannah wishes to get out of the ill-repute created in her life, she has been voiceless and this made people to leave their unwanted footprints in her life. Instead of wasting her time in explaining people that she is pure, she should have set a selfgoal. This self-goal would have made her keep moving in her life without any interruption and she would have worked hard to attain her goal. This reveals the absence of ideal self in the character of Hannah and it is one of the reasons for her suicide. Thus, she ended her life stating some reasons without recognizing the real purpose of her life.

Thus, self-concept is essential to live life with strength, courage and patience. This self-concept is not only for the individual, who suffers from suicidal thoughts. It is for every individual in the society, which would help them to know about, who they are and what this life really means to them.

\section{CONCLUSION}

Life is intertwined with problems and it is ineffectual for people to brood over it. There are strategies to unravel the every twists and turns of life. To learn the strategy, people should have patience to experience life, which helps them to analyze the twists and the reasons for it. This serves as a key to find the solution. People fall themselves, as reasons for the problems that they face in life, either knowingly or unknowingly. The bitter truth is that, they fail to realize that they are one of the contributors, for the problems that they face in life. The protagonist of 13 Reasons Why does the same, where she blames others for her death and for the consequences that she faced in her life. She doesn't realize the self-defects, hidden within herself and finally she ends her life.

Suicide cannot be the solution for problems in life and this act of killing oneself should be prevented. The basic suicide prevention methods are self-regulation, least expectation, being courageous, self-exploration and selfacceptance. Every individual should have control over their emotions, they should know their strength and weakness. They should not compare their life with others and they should spend money according to their living standards, this would help them to get rid of mental pressure due to depths.

People are in need to know their social roles and to maintain a smooth relationship with people, which would provide them a peaceful mind. Individual's expectations are bigger in this fast moving world, where they expect everything other than problems. Researcher says that, every individual should expect problems in their life, so that they would not get shocked after receiving what life has given 
them. This would help them to know the key to solve problems effectively. Individual can expect problems but should not invite problems voluntarily, their target should not be quite bigger and it should be achievable. Their expectations should not be high which would make them to get disappointed and this in turn results in depressive state of mind. Every individual should be bold enough to face the problems, which life gives them. If the individual gets abused, they should understand the fact that it is just their body which has been desecrated, but their soul is always consecrated with love and respect by their parents. Thus they should never think of taking away their life, which has been gifted by their parents. Here, in this novel, the protagonist also gets abused at the end and she takes away her life.

Carl Rogers's self-concept is the key to realize the self and its importance, which would preferably demolish the thought of killing oneself. The components stated under the self-concept are self-image, self-esteem and ideal self. These components are mandatory for individual to carry life with strength, will power and confidence. Individual with selfconcept should not stumble and expect others to hold on to them, rather they should motivate themselves. These three components lacks in the character of Hannah baker, the protagonist of the novel 13Reasos why. Self-image is knowing oneself and the purpose of life in this world, Hannah baker is not clear about herself and about the purpose of her life. "I stopped writing in my notebook when I stopped wanting to know myself anymore" (178). This shows Hannah's self-image as a weaker one. Self-worth is important to build the willpower and this portrays the individual as a self-esteemed person. Hannah is not regarded as a self-esteemed person, she lacks self-esteem and this makes her feel hopeless. This serves as reason for ending her life. Ideal self is the wish of people, whom they actually need to be. The protagonist fails to realize or experience what she really wants to be in this world, she wastes her time in mourning for worthless people. This shows the pathetic condition of Hannah Baker.

Despite the designation, class, race and sex, all should bow their head to mud to become mud. Death should be a natural one and it is unnecessary for people to lose their life by committing suicide. People do not possess any reason for their birth and at the same time they should not be the reason for their death. Every individual in this world has been predetermined by the celestial power. People came to this world by their parents and they feel secured but when they step into another world, they are in need to take up their social responsibilities. They should play the game of life successfully. Some people do not give up on their way and they make a moon walk. Some people give up and feel hopeless, where they fail to walk on razor's edge carefully. It is the game of life, which makes people to succeed and lose in life. People should note that, neither the success nor the failure would last till the last breathe. Hence, people need not lose their life by worrying about the burdens of their life.

\subsection{Findings}

The researcher after analyzing the character of Hannah Baker, the protagonist of 13 Reasons why tries to prove that low esteem would result in depression and hopelessness, which makes individual to commit suicide. The researcher made an attempt to prove that being voiceless, would make people to leave their unwanted footprints in other people's life. Hannah Baker suffers out of rumors created by her own friends and classmates, which show her as a voiceless character. Self-esteem plays a major role in the life of people to avoid suicidal behaviors and this has been stated through the character of Courtney, where she maintains her self-image in an appreciable sense.

\subsection{Limitations}

The researcher could not interview the suicide survivors personally, due to time constraints. The reasons behind suicide and suicidal thoughts have been derived out by analyzing the character through novel and it has not been stated out of direct experience. The characters in the novel could not clearly be synchronized with other characters, due to long narrative style.

\subsection{Scope for further study}

Research can be conducted by deconstructing the story and how the character Hannah Baker would have lived with pride and will power, if she has approached the situations in different manner. This would bring confidence and hope in the life of people, who are struggling with great problems. The research can be conducted by analyzing the characters around Hannah and the lack of quality in them, to exhibit their provoking attitude. This would help people to construct their character by knowing the defects.

Throughout the research, the researcher tries to prove that suicide is not the solution to solve problems. The researcher introduces various aspects to state a few reasons behind suicide and also tries to provide solution and better understating by implementing theories. The researcher introduces the self-concept, which involves self-image, selfesteem and ideal self. These three factors play a vital role to live life successfully and the researcher proves that without these three factors, an individual cannot lead life peacefully. 
This is exhibited by the character Hannah Baker, who lacks these three factors and she proves herself to be weak. Thus, she ends her life. This self-concept would help people to obviate suicide and would help to enrich hopefulness in their life. Thus, the researcher tries to state that the self-concept is essential to lead life with strength, courage and patience.

\section{ACKNOWLEDGEMENT}

I am thankful to the Almighty for showering his blessings on me to complete this article.

\section{REFERENCES}

[1] Asher, Jay. 13 Reasons Why. New York: Penguin Books, 2007. Print

[2] "Author Interview: Jay Asher on Thirteen Reasons Why." Cynthia Leitich Smith, 4 Jan. 2019, cynthialeitichsmith.com/2008/02/author-interview-jay-asheron-thirteen/.

[3] Farberow, Norman L. "The Role of the Family in Suicide." Suicide in Adolescence, 1987, pp. 139-152., doi: 10.1007/978-94-009-4253-0_9.

[4] Harris, Reginald. "Suicide in the Workplace." Monthly Labor Review, 6 Dec. 2016, doi:10.21916/mlr.2016.54.

[5] "MLR Articles by Stephen M. Pegula." U.S. Bureau of Labor Statistics, U.S. Bureau of Labor Statistics, www.bls.gov/opub/mlr/author/pegula-stephen-m.htm.

[6] "Preventing Teen Suicide." PsycEXTRA Dataset, 2010, doi: 10.1037/e530892011-001.

[7] Shea, Peter. "Thirteen Reasons Why." Thinking: The Journal of Philosophy for Children, vol. 20, no. 3, 2014, pp. 3-4., doi:10.5840/thinking2014203/41. 